\title{
Research on Dual-Class Share Structure and Company Performance
}

\author{
Shuai Wang \\ GuiZhou University of Finance and Economics
}

\begin{abstract}
This paper explores the relationship between dualclass share structure, agency cost and company performance, and divides the dual-class share structure according to multiple different dimensions of $B$ shares voting. With voting right as an alternative argument, this article studies voting rights and the relationship between company performance and adopts dualclass share structure of listed companies to determine reasonable $B$ shares multiples to provide theoretical reference for the right to vote. The paper mainly solves two key problems: first, under the background of dual-class share structure, whether voting right has a positive impact on company performance; second, what is the influence path of voting right on company performance? This paper will discuss whether voting right influences company performance through the mediating role of agency cost.
\end{abstract}

Keywords-Dual-class share structure; Agency cost; Company performance

\section{INTRODUCTION}

In August 2014, alibaba group went public in the United States as a whole, creating the largest IPO in history with a market value of more than 200 billion dollars. China's company law prohibits dual-class share structure in principle. According to the provisions of article 104 of the company law, shareholders attend the meeting to exercise the right to vote, each share has only one vote; Its article 127 provides for the principle of "one share, one right". It can be seen from these provisions that, in principle, China's company law requires "one share, one right, one share and one right". But neither theoretically nor legislatively negate dual-class share structure, but in practice so far there is no corresponding case. With the continuous improvement of China's market economy system, the reform and innovation of corporate governance structure are imperative. One of the amendments to China's securities law, which began in 2015, is a proposal to introduce a dualclass share structure. The domestic securities market is constantly changing. Although hkex missed the IPO of "BATJ" (baidu, alibaba, tencent, jingdong), we still have alipay, ant financial services, xiaomi... It is reported that shenzhen stock exchange is studying the feasibility of introducing dual ownership structure.

\section{LITERATURE REVIEW}

\section{A. Concept of Dual-Class Share Structure}

The concept of dual-class share structure, which originated from the United States, is an effective means to control the company by separating cash flow and control right, as opposed to the concept of "one share, one right" single-layer equity structure. Different from the system of the same share and the same right, in the dual-class share structure, shares are generally divided into two voting rights, namely, one common share of A and one voting share of B, which cannot be publicly traded and are generally contributed and held by the company's founders and founding team. High-voting shares have more decision-making power, and the fundamental purpose is to give founder shareholders "privileges", that is, through special equity structure design, original shareholders always retain the maximum decision-making power and control right in the process of multiple rounds of financing. In the traditional securities market, in order to maintain control, the founder team often reaches voting agent agreement with the newly introduced capital when it is newly introduced, which makes it give up voting right and only retain the right of profit. However, each time the voting rights agency agreement is signed, part of the interests of other parties will be given up to realize resource exchange. As the number of financing increases, the interest conflicts between the founder team and other shareholders will increase, which will reduce the efficiency of the company's operation. As an alternative method, ddual-class share structure is a long-term effect, and the use of institutionalized rules to avoid potential risks in the future is also one of its advantages.

According to the contract theory, the company itself is also a contract, and shareholders can independently choose the governance structure in line with the actual situation of the company through the articles of association, so as to achieve shareholder autonomy. Companies listed with dual-class share structure must be approved by the general meeting of shareholders. Dual-class share structure is a kind of entrustment contract of voting right reached between the founder team and shareholders. In a mature and rational securities market, the value of a company can be reflected through the market mechanism. If shareholders believe that the company has investment value, they will buy the shares of the company. If they believe that the dual-class share structure affects the value of the company, they can choose to "vote with their feet" and sell the shares of the company, which is a process of market selection. 


\section{B. Dimensions of Dual-Class Share Structure}

Although the dual class share structure has not been officially implemented in China, domestic enterprises can go abroad for listing in addition to listing in China. According to simple statistics, as of December 31, 2014, of the 168 mainland Chinese companies listed in the United States, a total of 34 (20.24\%) adopt dual-class equity structure, and their market value has exceeded $70 \%$ of the market value of all mainland Chinese companies listed in the United States. These companies cover the Internet, media, medical care, education and other industries, and are dominated by "Internet +", with 29 companies, accounting for $85.29 \%$ of the total.

Dual share structure is a kind of system. However, each company that adopts dual share structure adopts different voting multiples of B shares. We divide the dual share structure by different voting multiples of B shares. Among the 34 dualshare companies mentioned above, except alibaba and auto home (b-share voting power is dynamic, and different conditions correspond to different $b$-share voting power multiples), b-share voting power multiples are the highest for jd.com (20 times), the lowest for phoenix new media (1.3 times), and the most common for 10 times, there are 20 companies accounting for $62.5 \%$. In practice, each company founder group holdings, the final vote is ordinary voting of the A shares and make voting results after weighting of B shares, B shares of different voting may correspond to the same voting team for control of the company founder is same, so the B shares directly to the right to vote as A research variable does not make sense. This paper believes that voting right can be used as an alternative variable to study dual-class share structure, and then analyze the relationship between voting right and corporate performance. When an enterprise goes public with dual share structure, it can determine the voting power multiple of B shares based on the optimal voting power range and the shareholding ratio of the founder team.

\section{Research Status of Dual-Class Share Structure}

As for enterprises that are suitable for dual-class share structure, some scholars believe that companies adopting dualclass share structure are often high-growth companies. In the early stage of establishment, such companies often need huge capital investment to cultivate products favored by users, such as didi dache. They rely on high market coverage and user viscosity to achieve commercial success. But often do not have this kind of company can be used as a bank mortgage the underlying assets of the entity, because this kind of company's biggest asset is the company's technology, the application of high market coverage, or products and do not copy the business model, so inevitably at the start-up stage need to introduce all kinds of angel investors, venture capital and private equity funds. These companies often have to go through three to five rounds of financing before they have a chance to list on the stock exchange. During rounds of fundraising, the stakes in founders and management teams must be diluted with new outside investors. Often after three or five rounds of financing, the founders and management teams have far less shareholding in the company's institutional majority shareholders. At this point it is easy to produce a question: if the founders and management team can't control in absolute control of the company by the company's future development strategy and operation direction, this kind of start-up founder may be due to the management team and the management concept of the contradiction between large shareholders and eventually abandoned by highly competitive market.

There are two kinds of risks in implementing dual ownership structure. One is related transactions. A small equity stake may induce the controlling shareholder to transfer the assets of the listed company to another company in which they hold a higher stake, namely, the asset transfer and hollowing out the company. The other is agency cost. When the economic interests of controlling shareholders in the company are reduced, they are more likely to make profits for themselves (such as high salaries and benefits) at the expense of other shareholders. Dual class share structure allows the controlling shareholder to maintain control but hold a disproportionate number of shares in the company. Therefore, they have a greater incentive to use their control power for personal gain.

\section{RESEARCH HYPOTHESIS}

\section{A. The Relationship between Dual-Class Share Structure and Company Performance}

Equity includes voting right and cash flow right. The adoption of B shares with high voting right in dual-class share structure improves the voting right of founder management team, so dual-class share structure is essentially an equity incentive. Equity incentive is an effective incentive measure, which can significantly improve enterprise performance and effectively restrain the first type of agency cost, but the governance effect on the second type of agency problem is not significant. The first kind of agency cost plays a part of mediating role between equity incentive and enterprise performance, that is, equity incentive indirectly promotes enterprise performance by restraining the action path of the first type of agency cost, while the mediating role of the second type of agency cost does not appear.

The dual-class share structure gives the founder team higher voting rights, so the cash flow rights are relatively small, that is, the management team enjoys a smaller proportion of residual claim rights, so the income of cash dividend payment has less impact on it. The management team may not actively pay cash dividends, but use profits for the development and growth of the company, which is not conducive to the improvement of the company's value. The research on cash dividend on corporate performance shows that cash dividend significantly reduces the two types of equity agency costs, and then improves the performance of listed companies. The two types of equity agency costs play a significant part of the intermediary role in the process of cash dividend affecting corporate performance. Cash dividend policy generally shows a dominant governance effect. Moderate cash dividend is not only conducive to the protection of the interests of small and medium-sized investors, but also conducive to the improvement of the company's value.

The adoption of $\mathrm{B}$ shares with high voting rights in dualclass share structure will lead to the increase of ownership concentration. Scholars from different countries have different views on the relationship between ownership concentration and corporate performance. A large sample of Companies in the 
United States found that the relationship between the two is first positive correlation, then negative correlation, and finally positive correlation. The critical proportion is $5 \%$ and $25 \%$, respectively. The relationship between shareholder concentration and corporate performance presents a curve shape. Some scholars believe that the curve changes, but the critical point is different, according to the empirical results of $7 \%$ and $38 \%$. According to the empirical results, McConnell and Servaes (1990) believe that the relationship between the two presents an inverted U shape, from positive correlation to negative correlation, with a critical proportion of $40 \%$. Ekta (2005) put forward different viewpoints. He took Indian companies as samples and drew a conclusion that the relationship between them was U-shaped. Chinese scholars' empirical research conclusions on the relationship between the two are mostly focused on U-type relations, including positive $\mathrm{U}$ and inverted U-type relations. Supporters of positive Ushaped relationship believe that ownership concentration is negatively correlated with corporate performance first, reflecting the hollowing and tunneling effect. When equity concentration is raised, it is positively correlated with corporate performance, which is interpreted as the benefit convergence effect. Empirical scholars believe that the proportion of shareholding with inverted U-shaped relationship has an inflection point. Before $50 \%$, ownership concentration will reduce the value of the company, but beyond that. After $50 \%$, the value of the company is increased because the interests of shareholders and the company converge. This study considers that only when the concentration of equity is relatively moderate, can the company have a higher value. When the concentration of equity is too low or too high, it can not make the company have better performance. To sum up, we propose the following hypotheses.

H1:Under the dual-class share structure, the relationship between voting rights and corporate performance is inverted Ushaped.

\section{B. The Mediating Role of Agency Cost}

Dual-class share structure endows the founder team with high voting right, which belongs to the control right. In the traditional concept of "one share, one right" securities market corresponds to the ultimate control right, which refers to the voting right of listed companies directly or indirectly held by the ultimate controller of the company. The ultimate control right is the product of the principal-agent agreement and crossshareholding under the background of the same share and the same right. In the traditional securities market with the same share and the same right, due to the existence of crossshareholding and equity principal-agent, the game of resource interests exists between shareholders and between management team and shareholders, and the antagonistic relationship between them leads to high agency cost. Under the dual share structure, the system and regulations clearly endow the management team with corporate control rights. Shareholders mainly enjoy the cash flow rights and residual claims of the company, and there is no competition for control rights between them, thus greatly reducing agency costs. When dualclass share structure gives the founder team a particularly high voting right, the inconsistent interests between the company's executives and shareholders lead to opportunistic behaviors of the company's management. At this time, the absolute control brought by dual-class share structure will greatly increase agency costs. As for the relationship between agency cost and enterprise performance, most foreign scholars believe that with the increase of agency cost, enterprise performance will decrease accordingly. The agency cost was measured by the total asset turnover rate and the management expense ratio, and the empirical test was conducted with relevant data. It was also found that the agency cost would negatively affect the enterprise performance. When enterprises in different countries are taken as samples, the same conclusion can be drawn. The smaller the agency cost is, the smaller the negative impact on the value of the company will be, that is, the lower the agency cost is conducive to the performance of the company. To sum up, we propose the following hypotheses.

H2:Agency cost plays an Mediating role between voting right and company performance

\section{RESEARCH METHODS}

In order to test whether the above research hypothesis is valid, this paper, on the basis of Imai's mediating effect test model on causality and other internal factors that may affect corporate performance, finally proposes the following test model:

(1) $\mathrm{ROA}_{\mathrm{i}, \mathrm{t}}=\mathrm{a}_{0}+\mathrm{a}_{1} * \mathrm{VR}_{\mathrm{i}, \mathrm{t}}+\mathrm{a}_{2} *$ VRsquare $_{\mathrm{i}, \mathrm{t}}+\operatorname{contr}+\varepsilon_{\mathrm{i}, \mathrm{t}}$

(2) Agcost $_{i, t}=a_{0}+a_{1} * V_{i, t}+a_{2} *$ VRsquare $_{i, t}+\operatorname{contr}+\varepsilon_{i, t}$

(3) $\mathrm{ROA}_{\mathrm{i}, \mathrm{t}}=\mathrm{a}_{0}+\mathrm{a}_{1} * \mathrm{VR}_{\mathrm{i}, \mathrm{t}}+\mathrm{a}_{2} *$ Agcost $_{\mathrm{i}, \mathrm{t}}+\operatorname{contr}+\varepsilon_{\mathrm{i}, \mathrm{t}}$

In the model, ROA is the return on total assets, VR is the voting right, Agcost is the agency cost, Contr is the control variable, alpha is the regression coefficient and only the random disturbance term.

The selection of control variables is to exclude the influence of other irrelevant factors on corporate performance. According to previous research literature, this paper controls variables that may affect corporate performance, such as company size, financial leverage, enterprise growth ability, total asset turnover rate, equity incentive, board size and proportion of independent directors.

According to the procedure of intermediary effect test, this paper designs a distribution test as follows: first, the regression test of corporate performance (ROA) and voting rights (VR) is used to observe whether the regression coefficient of voting rights and corporate performance is significant, and if it is significant, the test is continued, if not significant, then it stops; second, to test whether the regression coefficient of agency cost(Agcost) and voting rights (VR) of intermediary effect variable is significant, if significant, continue to test, if not significant, stop; third, test whether the regression coefficient of voting rights and corporate performance is still significant after the agency cost of intermediary effect variable is added to the first step model, if not significant, then there is a complete intermediary effect, if still significant, then there is a partial intermediary effect. VRsquare is the square of voting rights. 


\section{SUMMARY AND DISCUSSION}

First, it provides theoretical support for the introduction of dual ownership structure in China. From the perspective of practice, the successful company examples in recent years have shown the feasibility of this dual ownership structure. It is increasingly common for Chinese Internet technology companies, such as baidu, youku, jd.com and phoenix new media, to go public with dual-class share structures. Therefore, in China's environment, the existence of dual ownership structure is feasible. More and more emerging Internet technology companies adopt this system. If China's stock exchange is still unwilling to relax the one-share-one-power rule, it can only weaken its competitiveness and push highquality companies to foreign stock exchanges.

Second, provide reference for soe reform. With the constant progress of China's market economy, one of the contents of the current reform of state-owned enterprises in China is to improve the shareholder composition of the company through mixed ownership, and achieve the effective balance of power between the board of directors and the management, so as to promote organizational management innovation and corporate governance. This is not an easy task to achieve. On the one hand, it is necessary to improve the level of openness and introduce capital from private enterprises and foreign companies. On the other hand, it is also important for them to control the core industries that are related to national economy and people's livelihood. Therefore, the separation of cash flow right and voting right and the dual ownership structure have application potential for the current soe reform, and the key goal of firmly grasping the control right can be met.

\section{REFERENCE}

[1] Thomas J. Chemmanur; Yawen Jiao. Dual Class IPOs: A theoretical analysis [J]. Journal of Banking and Finance, 2012,36(1):305-319.

[2] JW Howell. The survival of the U.S. dual class share structure [J]. Journal of Corporate Finance,2014,44.

[3] Beni Lauterbach; Yishay Yafeh. Long term changes in voting power and control structure following the unification of dual class shares[J]. Journal of Corporate Finance, 2011,17(2):215-228.

[4] Chen F, Zhao L L. To Be or Not to Be? - An Empirical Study on DualClass Share Structure of US Listed Chinese Companies[J]. Social Science Electronic Publishing, 2017.

[5] Chan R, Ho J. Should Listed Companies Be Allowed to Adopt DualClass Share Structure in Hong Kong?[J]. Common Law World Review, 2014, 43(2):155-182.

[6] Sharfman B S. A Private Ordering Defense of a Company's Right to Use Dual Class Share Structures in IPOs[J]. Social Science Electronic Publishing, 2017.

[7] Jordan B D, Kim S, Liu M H. Growth opportunities, short-term market pressure, and dual-class share structure[J]. Journal of Corporate Finance, 2016, 41:S0929119916301444.

[8] Winden A. Sunrise, Sunset: An Empirical and Theoretical Assessment of Dual-Class Stock Structures[J]. Social Science Electronic Publishing, 2017.

[9] Lauterbach B, Yafeh Y. Long term changes in voting power and control structure following the unification of dual class shares[J]. Journal of Corporate Finance, 2011, 17(2):215-228. 